\title{
STATUTORY LIMITATION PERIODS \\ IN ALBERTA STATUTES: 1975 UPDATE
}

In the third issue of its 1974 volume the Alberta Law Review presented the first comprehensive compilation of limitation periods in Alberta statutes done since 1962. The materials presented in the current volume are an effort to continue this project on an annual basis.

As was the case with the 1974 compilation, these materials were prepared by the Institute of Law Research and Reform at the request of the current editor of the Alberta Law Review. While every effort at thoroughness has been made, the Institute of Law Research and Reform does not represent the absolute accuracy or absolute coverage of the limitation periods in the 1975 Statutes of Alberta.

Again, it should be noted that no reference has been made to the Alberta Regulations with respect to limitation periods, and the reader is advised to have regard to the provisions of the Interpretation Act, R.S.A. 1970, c. 189 with respect to the computation of time.

Prepared by:

Staff of The Institute of Law Research and Reform The University of Alberta 


\section{Statute}

The Agricultural Service Board Act, R.S.A. 1970 , c. 7 as amended by 1975 , c. 40 .

\section{Action or Remedy}

8. 19.1-The Minister of Municipal Affairs, a council or a board shall not perform any work on the land pursuant to a declaration or order made or by-law passed under section 16 or 19 , as the case may be, until not less than ...

(a) upon the registered owner of the land (i) by means of personal service, or

(ii) by sending it by registered mail to his latest address on file at the and land titles office,

(b) upon all other persons shown on the records of the land titles office to have an interest in the land

(i) by means of personal service, or

(ii) by sending it by registered mail to those persons at their latest address on file at the land titles

office.

s. 19.2(2)-An appeal under subsection (1) may be brought...

s. 19.2(4)-Where

(a) an appeal of a declaration, order or by-law is commenced ..., and

(b) work has been performed upon the land pursuant to the declaration, order or by-law,

the cost of that work shall be borne by the person commencing the appeal, and if that person is the registered owner of the land or is the person who is in possession or occupation of the land, the amount of those costs remaining unpaid shall be

(c) added to the taxes against the land, and

(d) deemed to be taxes for the purpose of proceedings for recovery under The Tax Recovery Act.

s. 20(3)-Where an order made or by-law passed under section 19 , subsection (2) is not rescinded under subsection (1), it shall lapse on ...

s. 20.1(2)-An application under subsection (1) may be made upon ... to the registered owner of the land and any other person who is in possession or occupation of the land or, where the Court is satisfied that it is in the public interest to do so, the application may be made ex parte.

s. 20.1(3)-Where an order is made pursuant to an ex parte application, any person affected by that order may, upon ... apply to the Court to have the order varied or set aside and upon hearing the matter the court may refuse the application or vary or set aside the order upon such terms and conditions as the Court considers proper. s. 20.1(4)-An order made under this section lapses...

\section{Limitation Period}

30 days have transpired from the date that a certified copy of the declation, order or by-law has been served.

at any time during which the declaration, order or by-law is in force.

30 or more days after that declaration, order or by-law has been served under section 19.1.

the first day of March in the third year in which the order was made or the by-law was passed. two day's notice.

two day's notice to the Minister of Municipal Affairs or the council, as the case may be,

30 days from the date that the order is made. 
Statute

Boilers and Pressure Vessels Act, S.A. 1975, c. 4 .

The Chartered Accountants Act, R.S.A. 1970, c. 42 , as amended by 1975 , c. 44

The Child Welfare Act, R.S.A. 1970, c. 45 as amended by 1975 , c. 80 .

The Companies Act, R.S.A. 1970 , c. 60 as amended by 1975, c. 44 .

\section{Action or Remedy}

s. 33(2)-The person making the investigation shall give the owner or person in charge of the boiler, pressure vessel, power plant, heating plant, or pressure plant in respect of which an investigation is to be held, not less than ... of the commencement of the investigation and its purpose.

s. 39(1)-At least . . a a notice in writing shall be served upon the person whose conduct, capability or fitness is the subject of the inquiry

(a) containing reasonable particulars of the matter to be investigated, and

(b) specifying the time and place of the hearing.

s. 43(1)-A person who is the subject of an order of a Committee of inquiry may, within ...., appeal to the Supreme Court of Alberta.

s. 54-Where a professional corporation ceases to fulfil any condition specified in section 53 , subsection (3) other than clause (g) by reason only of

(a) the death of a member, or

(b) the striking off or other removal from the register of the name of a member, or

(c) the suspension by the Council of a member,

who is a shareholder of the corporation, the professional corporation has a period of ...., in which to fulfil the condition failing which the permit is automatically terminated effective upon the expiration of the ... without the necessity of an order of the council.

s. 86(7)-Upon receipt of an application for a hearing to review the confinement of a child, the judge shall direct that there be a hearing within .... before himself or before any other judge of the Juvenile Court designated by him, for the purpose of conducting a review of the confinement of the child in respect of whom the application is made.

s. 16(2)-Notwithstanding subsection (1), clause (a), a company limited by shares

(a) may be incorporated under a name which does not include the word "Limited" or "Ltd.", and

(b) may change its name in accordance with section 32 to exclude the word "Limited" or "Ltd.",

if the company is incorporated, or its name is changed, as the case may be, for the purpose of making application for the issuance of a permit to operate as a professional corporation under The Chartered Accountants Act, The Dental Association Act, The Legal Profession Act or The Medical Profession Act, 1975 and if the company undertakes to change its name to include the word "Limited" or "Ltd." within ....

\section{Limitation Period}

24 hours' notice in writing.

14 days before a committee of inquiry commences hearings for the purpose of taking evidence or otherwise ascertaining facts.

30 days of the date of the order.

90 days from the date of the death, striking off, other removal or suspen. sion, as the case may be.

90-day period

10 days.

90 days after the com. pany ceases to hold a subsisting permit. 
Statute

The Companies Act, R.S.A. 1970 , c. 60 as amended by 1975 , c. 46
The Credit Union Act, R.S.A. 1970 , c. 74 as amended by 1975, c. 48 .

\section{Action or Remedy}

8. 16(3)-The Registrar, after having given notice to the company of his intention to do so, may by order change the name of a comcompany limited by shares to include to word "Limited" or "Ltd." if it is shown to the satisfaction of the Registrar that the company has carried on business for a period exceeding ...

\section{8. $188(1)$-Where}

(a) a company or an extra-provincial company

(i) has failed to file any return, notice or document required to be filed with the Registrar pursuant to this Act for...., or

(ii) has not complied with an undertaking it made under section 11 , subsection (3) to dissolve or change its name within ..., or

(b) the Registrar has reasonable cause to believe that

(i) a company is not carrying on business or is not in operation, or

(ii) an extra-provincial company has ceased to carry on business in Alberta,

he shall send by mail to the company or to the extra-provincial company a letter requiring it

(c) to file any return, notice or document that has not been filed, or

(d) to comply with an undertaking given under section 11, subsection (3), or

(e) to notify the Registrar

(i) in the case of a company, as to whether it is carrying on business or is in operation, or

(ii) in the case of an extra-provincial company, as to whether it has ceased to carry on business in Alberta.

8. 73(2)-The Director shall give the credit union not less than ... specifying the reason for the proposed dissolution and stating that unless cause is shown to the contrary the Registrar will be directed to strike the credit union off the register.

s. 84(2)-Subject to subsection (3), a member of the Board holds office for a term of ..., or until his successor is appointed or elected in his stead.

s. 93(4)-Each credit union shall pay to the Corporation the amount of its assessment within ...

\section{Limitation Period}

90 days while not the holder of a subsisting permit as a professional corporation issued under The Chartered Account. ants Act, The Dental Association Act, The Legal Profession Act or The Medical Profession Act, 1975.

two consecutive years after the return, notice or document should have been so filed.

six months after the incorporation of another company with a similar name

two months' notice of the proposed dissolution.

two years from the date of his appointment or election, as the case may be

30 days after notice of the assessment is sent or within such extended time as the Board may fix. 
Statute

The Dental Association Act, R.S.A. 1970 , c. 90 as amended by 1975 , c. 44 .

The Department of Government Services Act, S.A. 1975, c. 11 .

\section{Action or Remedy}

s. 96(2)-Every claim under subsection (1) shall be made within ...

s. 96(3)-In the case of a person who is under 18 years of age at the time when the claim under subsection (1) first arose, the claim may be made by his parent or guard. ian, or if not so made, may be made by the person himself within ...

s. 96(4)-Notwithstanding subsections (2) and (3), the Board may receive any claim ... and may make payment based on any claim so received.

s. 97(1)-Where a member of a credit union is entitled to claim against the Corporation in respect of any share or deposit, or both, the Corporation shall, .... make payment thereof to such member or to his personal representative.

s. 102(9)-Every credit union or person shall reply ..., and in writing, if so required, to an inquiry made pursuant to subsection (8), s. 102(10)-Where the Corporation has placed any credit union under its supervision, the credit union may within .... appeal to the Director in writing for the removal of the declaration of supervision.

s. 102(11)-Where an appeal is commenced under subsection (10), the Director shall, ...., render a decision either continuing or removing the declaration of suspension.

s. 70(4)-A permit issued under subsection (3) expires on ...

s. 71-Where a professional corporation ceases to fulfil any condition specified in section 70 , subsection (3) by reason only of

(a) the death of a member, or

(b) removal of a member's name from the register, or

(c) the suspension by the Association of a member,

who is a shareholder of the Corporation, the professional corporation has a period of ... in which to fulfil the condition failing which the permit is automatically terminated effective upon the expiration of the ...

8. 11(5)-Subject to any other Act, all lost or unclaimed property in the custody of the Government of Alberta shall be retained for...

s. 11(6)-If not claimed within . . , the Minister may dispose of the property on behalf of the Government of Alberta.

\section{Limitation Period}

six months of the time when the credit union failed, refused, or neg. lected to return the moneys invested or deposited.

six months from the date on which he attains the age of 18 years.

after the expiry of the time limitations in subsections (2) and (3).

as soon as practicable upon receipt of notice of the claim in a form approved by the Board and upon the Board being satisfied as to the correctness of the amount of such claim.

promptly.

30 days after the declaration of supervision by the Corporation,

within 15 days from the date of hearing the appeal,

December 31 of the year for which it was issued.

90 days from the date of death, striking off or suspension, as the case may be,

90-day period without the necessity of an order of the board.

one year from the time the property came into the custody of the Government.

one year from the date that the property came into the custody of the Government. 
Statute

The Department of Manpower and Labour Act, S.A. 1972 , c. 35 as amended by 1975 , c. 14 .

The Department of Transportation Act, S.A. 1975, c. 17.

The Election Act, R.S.A. 1970 , c. 117 as amended by 1975 c. 52 .

The Highway Traffic Act, S.A. 1975 , c. 56.
Action or Remedy

s. 11(8)-No claim may be made

(a) to the property after... unless the property is still in the custody of the Government, or

(b) to the proceeds of the sale of the property after...

8. 5.2(5)-Where an employer fails to obey an order given under subsection (4), the Minister may apply to the Supreme Court by way of originating notice, on not less than ... for an injunction or other order and the Court may grant or refuse the injunction or other order or make any other order that in its opinion the justice of the case requires.

8. $15(5)$ - The employee is entitled to retain the motor vehicle he tests and inspects for .... . but after . . . he shall upon request of the owner release it to him.

s. 58(3)-At least ... the returning officer shall deliver to each deputy returning officer one ballot box and the materials set forth in Form 26.

s. 14(1)-With respect to highways under its direction, control and management, the council of a municipality may make bylaws, not inconsistent, with this Act and on matters for which no provision is made in this Act, for the regulation and control of vehicle, animal and pedestrian traffic and, without restricting the generality of the foregoing, may make by-laws

16. providing for the seizure or impound. ing for a period not exceeding . . . of any bicycle used or operated in contravention of any by-law,

19. granting a licence or permit for the temporary occupation or use of a road allowance, public highway, or a portion thereof when it is not required for public use if the licence or permit is terminable upon ... .

8. 115(3)-A vehicle left standing, at a location referred to in subsection (1) or (2), for more than ... shall be deemed to have been abandoned at that location for the purposes of section 96 of The Motor Vehicle Administration Act.

8. 152(1)-In any prosecution under this Act or the regulations or under The Public Service Vehicles Act or the regulations under that Act or under a municipal by-law, a certificate

(a) stating the result of a test of

(i) the speedometer of a motor vehicle identified therein, or

(ii) a tuning fork identified therein and used for determining the accuracy of a radar set, or
Limitation Period

one year from the date that the property came into the custody of the Government.

one year from the date that the property was disposed of by the Department.

three days' notice.

21 days from the date of the accident.

21 days.

two days before polling day.

60 days.

30 days' notice in writing.

72 consecutive hours. 
Statute

The Alberta Income Tax Act, R.S.A. 1970 , c. 182 , as amended by 1975 , c. 22 .

The Alberta Labour Act, S.A. 1973 , c. 33 as amended by 1975 , c. 60 .

\section{Action or Remedy}

(iii) any other device identified therein and used for in connection with establishing the speed of vehicles,

(b) bearing a date thereon not more than,

(i) in the case of a tuning fork, ..., or

(ii) in the case of a speedometer or other device used for or in con. nection with establishing the and speed of vehicles, . . . ,

(c) purporting to be signed by a tester appointed under this Act to test devices of the type stated to have been tested,

shall be admitted in evidence as prima facie proof of the facts stated therein without proof of the signature or appointment as a tester of the person signing the certificate. s. 8.5(8)-An agreement referred to in subsection (7) shall be filed with the Provincial Treasurer but if no agreement is filed within .... the Provincial Treasurer shall, for the purpose of this section, allocate an amount to one or more of them for the taxation year, which amount or the aggregate of which amounts, as the case may be, shall be equal to the maximum allowable credit for the taxation year, and in any such case, notwithstanding subsection (7), the maximum allowable credit for the taxation year for each of the associated corporations is the amount allocated to it under this subsection.

8. 33.1(1)-Notwithstanding The Individual's Rights Protection Act, the Board after such inquiry as it considers necessary may, with the approval of the Lieutenant Governor in Council, make an order

(a) requiring an employer to grant to a pregnant employee maternity leave without pay for any period between ..., subject to such conditions as are considered necessary;

(b) governing the conditions under which maternity leave referred to in clause (a) may be shortened or extended;

(c) governing the conditions whereby an employer may, by notice in writing, require a pregnant employee to commence maternity leave without pay during all or any part of that period referred to in clause (a) when the pregnancy is interfering with the performance of the employee's work;

(d) governing the manner in which an employee who has commenced maternity leave is to be reinstated by an employer;

\section{Limitation Period}

one year before or after the date of the offence charged.

30 days before or after the date of the offence charged,

30 days after notice in writing by the Provincial Treasurer has been forwarded to any of the associated corporations that such an agreement is required for the purposes of this section.

(i) 12 weeks before the estimated date of delivery of the child and

(ii) six weeks after the actual date of delivery of the child. 
Statute

The Land Titles Act, R.S.A. 1970 , c. 198 as amended by 1975, c. 43.

The Landlord and

Tenants Act, R.S.A 1970 , c. 200 , as amended by 1975, c. 24 .

The Legal Profession Act, R.S.A. 1970, c. 203 as amended by 1975 , c. 44.

\section{Action or Remedy}

(e) prohibiting an employer from terminating the employment of or laying off a pregnant employee within the period referred to in clause (a) for any reason specified in the order,

(f) specifying the length of any notice in writing required to be given by a pregnant employee or by an employer;

(g) providing for any other matter or thing, including the imposition of restrictions or conditions on pregnant employees and employers or either of them, to establish a means of providing that a pregnant employee is not prejudiced by reason of the pregnancy with respect to employment or with respect to the wages and other benefits that had accrued to the employee to the date that the employee commenced maternity leave without pay.

s. 161(7)-Where any amount charged to the credit of a person under subsection (6) is not paid within . . ., no further amounts may be charged to the account of that person until all amounts owing are paid in full.

8. 161(8)-The Registrar may terminate an agreement under subsection (5) with any person upon .... sent by registered mail to the person at his last address known to the Registrar.

s. 21.1(2)-Where, after the commencement of a tenancy of residential premises,

(a) a condominium plan is registered or is proposed to be registered in the Land Titles Office and includes or is proposed to include those residential premises, and

(b) a notice of termination of that tenancy is given to the tenant for the purpose of obtaining vacant possession of the residential premises in order that the residential premises or any part thereof may be sold as a condominium unit or as part of a condominium unit,

the notice of termination is void unless it provides that the tenancy is to terminate as of the day not less than ...

s. 113(4)-A permit issued under subsection (3) expires on ...
Limitation Period

15 days, or such other period as the Registrar may require, of a request for payment by the Registrar.

seven day's notice in writing. six months after the day on which the notice is given to the tenant.

December 31 of the year for which it was issued. 
Statute

The Livestock Brand Inspection Act, S. A. 1971 , c. 63 , as amended by 1975 , c. 63 .

The Marriage Act, R.S.A. 1970 , c. 226 , as amended by 1975 , c. 64 .

The Medical Profession Act, S.A. 1975 , c. 26 .

\section{Action or Remedy}

8. 114-Where a professional corporation ceases to fulfil any condition specified in section 113 , subsection (3) by reason only of the death or loss of active membership in the Society of a shareholder of the company, the professional corporation has a period of ..., in which to fulfil the condition failing which the permit is automatically terminated effective upon the expiration of the ... without the necessity of an order of the Benchers.

s. 6(5)-Any person receiving a copy of a livestock manifest shall retain it for a period of .... and produce the copy for inspection upon demand by an inspector during that period.

s. 23(6)-Each licence expires on ...

s. 31(6)-Where a notice is issued under subsection (2) for any livestock and, after a period of . . . has elapsed, an inspector is unable to determine the ownership of the livestock, the inspector shall issue a release in the prescribed form instructing the withholding settlement to forward the amount so withheld to the Provincial Treasurer and such amount shall form part of the General Revenue Fund.

s. 27(1)-No person shall issue a marriage licence or solemnize a marriage where he knows or has reason to believe that there is in effect with respect to a party to the intended marriage

(a) a declaration under The Mental Incapacitated Persons Act that the party is of unsound mind or is incapable of managing his affairs, or

(b) a certificate of incapacity under The Mental Health Act, 1972, unless there is delivered to him a certificate under subsection (2) and, where there is a committee of the estate of a party to the intended marriage, proof that the committee of the estate of a party to the intended marriage, proof that the committee has been given at least...

8. 4(2)-The registrar shall, at least ..., prepare an alphabetical list of the registered practitioners showing the district in which each resides and is entitled to vote.

s. 8(1)-A registered practitioner may petition the council against the election of a member by filing the petition with the registrar within ...

8. 29(2)-For the purpose of subsection (1), clause (a), where the registrar has neither registered nor refused to register a person within ...., the application shall be deemed to have been refused.
Limitation Period

90 days from the date of the death or loss of active membership, as the case may be,

90 day period.

two years.

December 31 of the year for which it is issued.

60 days.

14 days' prior notice of the issuance of the licence or the solemnization of the marriage, as the case may be.

two months before the date on which the election is to be held.

15 days after the election.

60 days of that person having applied for registration. 
Statute

The Medical Profession Act, S.A. 1975, c. 26, as amended by 1975 , c. 44 .

\section{Action or Remedy}

8. 48(1)-At least . . . , a notice shall be served upon the person whose conduct or capability or fitness is the subject of inquiry

(a) containing reasonable particulars of the matter to be investigated, and

(b) specifying the time and place of the meeting.

8. 55(4)-The council shall, at or within ..., issue its decision.

8. 56(6)-Where the council has ordered that the registered practitioner's name be struck off the register, the council may at any time order that the practitioner's name be reinstated on the register but no application for the reinstatement of a name to the register shall be considered until .... un. less the applicant has complied to the satisfaction of the council with any conditions prescribed by the council.

8. 58(1)-A registered practitioner who is subject to an order of the council under this Part may, within .... appeal to the Appellate Division of the Supreme Court of Alberta.

8. 58(2)-The appeal shall be commenced by

(a) filing a notice of appeal with the Registrar of the Court at Edmonton or Calgary, and

(b) serving a copy of the notice of appeal upon the registrar of the College, within ...

8. 72-A prosecution under this Part may be commenced at any time within ...

8. 87(4)-A permit issued under subsection

(3) expires on ...

8. 88-Where a professional corporation ceases to fulfil any condition specified in section 87 , subsection (3) by reason only of

(a) the death of a registered practitioner, or

(b) the striking off or other removal from the register of the name of a registered practitioner, or

(c) the suspension of a registered practitioner by the College,

who is a shareholder of the corporation, the professional corporation has a period of .... in which to fulfil the condition failing which the permit is automatically terminated effective upon the expiration of the ...
Limitation Period

two weeks before the meeting of an investigating committee held for the purpose of taking evidence or otherwise ascertaining the facts.

a reasonable time after the conclusion of all proceedings before it.

one year from the date when the name was struck off the register.

30 days of the date of the service of the order on the registered practitioner, his counsel or agent.

30 days of the date of service of the order on the registered practitioner, his counsel or agent.

12 months after the commission of the offence, but not thereafter.

December 31 of the year for which it was issued.

90 days from the date of death, striking off or other removal or the sus. pension, as the case may be,

90-day period without necessity of an order of the council. 


\section{Statute}

The Mental Health Act, S.A. 1972 , c. 118 as amended by 1975 , c. 65 .

The Motor Vehicle Administration Act, S.A. 1975 , c. 68 .

\section{Action or Remedy}

8. 28(2)-Where a person is detained under

(a) a conveyance and examination certificate, or

(b) one admission certificate,

that person shall be released upon the expiry of ... unless there are, within that time, two admission certificates in effect with respect to that person.

8. 14(6)-A medical examination certificate filed under subsection (4) must have been completed within ...

8. $18(3)$-The holder of any operator's licence which is suspended or cancelled shall ... return the operator's licence to the Registrar.

s. 21(2)-The Board shall not suspend or restrict an operator's licence or a person without giving him at least ... and giving him an opportunity to be heard in person or by counsel.

8. 23(1)-Where the Board has suspended the operator's licence of a person for an indefinite period or for a period in excess of . . . the person may apply to the Board for a review of the suspension and the Board shall, ..., give him an opportunity to be heard.

8. 23(2)-No person may apply for a review under subsection (1) more often than once every ...

s. 23(4)-Any person who considers him. self aggrieved by a decision of the Board may, within .... appeal the decision of the Board to a judge of the District Court.

8. 40(2)-When the ownership of a registered commercial vehicle passes from the registered owner to any other person, whether by an act of the owner or by the operation of law, the registration of the vehicle expires upon the ...

s. 40(3)-When the ownership of a registered public service vehicle passes form the registered owner to any other person, whether by an act of the owner or by the operation of law, the registration of the vehicle expires ...

8. 40(4)-The registered owner of the vehicle or his legal representative shall, not later than ...., deliver to the Minister the certificate of registration of the vehicle.

s. 40(5)-The new owner of the vehicle or his legal representative may, not later than .... apply to the Minister for

(a) the registration of the vehicle in the name of the new owner or his legal representative, and

(b) the transfer of the licence plates accordingly.

\section{Limitation Period}

24 hours from the time that the person arrived at the facility.

180 days prior to the date of filing.

forthwith.

10 days' notice in writing.

six months.

within 30 days.

six months.

30 days after the decision of the Board is sent to his latest address as recorded with the Board. 14th day after the day upon which the ownership passes.

at the time the ownership passes.

the 14th day after the ownership so passes.

the 14th day after the ownership so passes. 


\section{Action or Remedy}

s. 40(6) When the ownership of a registered vehicle passes from the registered owner to any other person, the licence plates issued upon registration may, not later than ..., be reissued to the registered owner for use upon another vehicle owned by him, upon

(a) compliance with the regulations,

(b) production of satisfactory proof of ownership of the other vehicle, and

(c) payment of the prescribed fee.

s. 40(7)-Where the ownership of a registered vehicle passes from the registered owner, either by an act of the owner or by the operation of law, to a person engaged in the business of selling or dealing in vehicles, whether new or otherwise, or engaged in the business of automobile wreckage, that person, if the licence plates issued to the registered owner come into his possession, shall return the plates ... to the Minister.

s. $40(8)$-Where the ownership of a commercial vehicle passes from one person to another and the new owner intends to apply for the registration of the vehicle in his name, and

(a) to have transferred to him the licence plates issued to the registered owner of that vehicle, or

(b) to have reissued to him for use on that vehicle licence plates issued to him upon the registration of another motor vehicle,

then, notwithstanding sections 34 and 51 , the new owner may display those licence plates on the vehicle and operate or permit another person to operate the motor vehicle on a highway for no more than ...

s. 41(2)-Where the ownership of a registered vehicle passes from the registered owner to any other person, whether by an act of the owner or by operation of law, the registration of the vehicle expires ... and the registered owner shall remove the licence plates from the vehicle and retain them in his possession.

s. 41(3)-At any time during the registration year for which the licence plates are issued, the person to whom they are issued may apply to the Minister to use the plates on another vehicle to be registered in his name, if the application is made within ... and, notwithstanding sections 34 and 51 , that person may display the plates on the newly acquired vehicle and operate or permit another person to operate the vehicle on a highway ...
Limitation Period

14 days after the passing of ownership.

forthwith.

14 days after the ownership passes to him.

forthwith.

14 days after acquiring ownership of the other vehicle. 


\section{Action or Remedy}

8. 41(5)-Where the ownership of a registered vehicle passes from the registered owner, either by an act of the owner or by operation of law, to another person that other person, if the licence plates issued to the registered owner come into his possession, shall return the plates ... to the Minister.

8. 41(6)-Notwithstanding subsections (2) and (3), where a vehicle is registered under the names of both a lessor and lessee, and the lessee ceases to have an interest in the vehicle, the lessor shall retain the licence plates in his possession and may apply within ... to have registration include the new lessee of the vehicle.

8. 62(1)-Where

(a) a judgment for damages arising out of a motor vehicle accident is rendered against a person by the court in Alberta or in any other province or territory of Canada, and

(b) that person fails, within ...., to satisfy the judgement

the Minister, subject to sections 63 and 64 , may suspend the operator's licence of that person and may suspend the registration of any or every motor vehicle registered in the name of that person.

8. 88-Where a motor vehicle is stored in or left at a public garage, parking station, parking lot, used car lot, repair shop or on any private property is unclaimed for ... the person in charge of the place where the motor vehicle was stored or left shall ... report the presence of the unclaimed motor vehicle to the police department having jurisdiction in that area, giving the liceceplate number and description of the motor vehicle and such information as he may have relating to the person storing or leav. ing the vehicle at his place of business.

s. 92(3)-Where a person submits to the taking of a specimen of his breath the person testing the specimen shall , ..., give him a signed statement of the result of the test.

8. 93-Every person who, being in possession of a motor vehicle for which a customs permit has been obtained in respect of its entry into Canada and who being requested by a peace officer to produce the customs permit, refuses or fails to produce the permit within ... is guilty of an offence.

s. 96(2)-All reasonable costs incidental to the removal of a vehicle pursuant to subsection(1) and the storage thereof, for a period not exceeding . ..., constitute a debt owing to the Crown by the registered owner of the vehicle or any subsequent purchaser.

\section{Limitation Period}

during that 14 day period.

forthwith.

14 days after having leased to vehicle to a new lessee.

15 days from the date upon which the judgement became final.

30 days or more.

immediately.

as soon as reasonably possible.

a reasonable time.

six months. 
Action or Remedy

8. 96(4)-Where a vehicle stored pursuant to this section

(a) is not registered in Alberta, or

(b) is not, within ..., claimed by the registered owner or someone on his behalf in return for full payment of the removal and storage costs actually paid,

the vehicle may, upon the approval in writing of the sheriff of that judicial district, be disposed of by public auction or otherwise as the sheriff shall direct, subject to the giving of written notice of the proposed sale to the holders of encumbrances registered in respect of the vehicle at the Central Registry of the Department of the Attorney General and the proceeds of the sale shall be expended in the following order:

(c) to pay the debt owing to the Crown under this section;

(d) to pay the balance owing on any encumbrances referred to in this sec. tion, to the rightful persons;

(e) to pay any remaining portion to the Registrar who shall deposit the amount in the Motor Vehicle Accident Claims Fund established under The Motor Vehicle Accident Claims Act whereupon the amount

(i) shall be paid by the Registrar to any person who provides proof satisfactory to the Registrar that the person is entitled thereto if the claim is made and proof thereof is established within one year of the removal of the vehicle under subsection (1), or

(ii) shall constitute a part of the Motor Vehicle Accident Claims Fund if no claim is made and established as provided in subclause (i).

s. 99(4)-If proceedings are not taken under this Act within ... the motor vehicle shall be ... returned to the owner thereof.

8. 110(4)-A suspension or disqualification arising pursuant to this section terminates upon the expiration of ...

s. $112(3)-A$ registered owner who does not within ... deliver both the certificate of registration and licence plates to the Registrar in accordance with subsection (2) is guilty of an offence.

The Municipal

Government Act,

R.S.A. 1970 , c. 71 as

amended by 1975 , c. 69 .
Limitation Period

30 days of its removal.
10 days after the motor vehicle is seized and detained pursuant to subsection (1) forthwith.

24 hours from the time the suspension or disqualification arose.

14 days from the date of the order.

14 days of the date on which the request in writing was delivered to the mayor under subsection (1). 
Statute

Action or Remedy

or within ...

The Optometry Act, R.S.A. 1970 , c. 270 as amended by 1975 , c. 72 .

The Pipeline Act, S.A. 1975 , c. 30 . Association within ...

s. 16-The Board may s. 15(1)-The Registrar shall issue a certificate of registration as a member of the

s. 34(1)-The council may, after . . , suspend a member who is in default for a period of at least ... of payment of an amount owing by him to the Association as a fee, contribution or fine or as costs.

(a) cancel a permit if a date was prescribed pursuant to section 14 by which the construction of the pipeline was to be commenced or completed and the pipeline was not commenced or completed ...., or

(b) amend a permit if it considers it to be in the public interest to do so, or

(c) cancel a permit at the request of the permittee, or

(d) issue a new permit in place of a cancelled permit.

8. 17(1)-Where, in the opinion of the Board, a permittee has not substantially commenced construction of the pipeline for which his permit was issued within ..., the Board may cancel the permit.

s. 17(2)-Where, in the opinion of the Board, a permittee has not completed construction of the pipeline for which his permit was issued within ..., the Board may cancel the permit.

s. 17(3)-A permit issued prior to the commencement of this Act shall not be cancelled pursuant to this section until...

s. 19(2)-A person who is operating a pipeline at the commencement of this Act for which no licence was required under The Pipeline Act shall, within ..., obtain a licence under subsection (1) and shall be deemed not to be in contravention of subsection (1) during that period prior to obtaining the licence.

s. 21-A licence granted provisionally by the Board may be for any period not exceeding ... but the Board upon application, may extend the period if, in its opinion, circumstances warrant it.

s. 25(3) - If any address registered under subsection (1) is changed or if the agent appointed in accordance with subsection (1) is changed or ceases to act, the permittee or licensee shall, within ... register the change with the Board.

\section{Limitation Period}

14 days of the date on which the request was made under subsection (2) or (s).

14 days after the receipt of the registration fee, the current annual fees and a copy of the certificate of approval for registration.

14 days' notice to the member 60 days.

by that date.

one year from the date of the permit.

18 months from the date of the permit.

six months have elapsed after the commencement of this Act.

two years of the commencement of this Act in the case of a flow line or within six months of the commencement of this Act in any other case.

six months.

15 days thereof. 
Statute

The Real Estate Agents' Licensing Act, R.S.A. 1970 , c. 311 as amended by 1975 , c. 76

\section{Action or Remedy}

s. 26-Where a permittee or licensee of a pipeline or proposed pipeline changes his name he shall ... advise the Board in writing and the Board may amend the permit or licence accordingly.

s. 29(2)-Where a representative of the Board makes an order under subsection (1), clause (a) or (b), he shall, ... , report to the Board and advise in writing the permittee or licensee, if any, setting out the reasons for his action.

s. $30(1)$-Where the construction or operation of a pipeline is suspended pursuant to section 29 , subsection (1), clause (b), the Board, within . . . , shall hold an inquiry to investigate the circumstances leading to the suspension.

s. 30(2)-Where the adoption of approved methods or equipment or the taking of remedial measured is ordered pursuant to section 29, subsection (1), clause (a) and the construction or operation of the pipeline is suspended pending conformity with the order, the permittee or licensee may request an inquiry and if he does so, the Board shall hold an inquiry within ...

8. 31(1)-Within .... the Board may

(a) allow the construction or operation of the pipeline to continue or resume subject to such conditions as the Board may prescribe, or

(b) order the continued suspension of the construction or operation of the pipeline until such time as the Board orders to the contrary, or

(c) cancel or suspend the permit or licence for the pipeline.

s. 52-No prosecution for an offence under this Act shall be commenced more than ...

s. 9(2)-A person who wishes to appeal the decision of the Superintendent under this section shall, within ... , serve the Minister with a notice of appeal.

s. 9(3)-Upon being served with a notice of appeal under section (2), the Minister shall, within ... , appoint an appeal board to hear the appeal.

s. 9(6)-Where a person is dissatisfied with the decision of the appeal board, that person may appeal the decision of the appeal board to the Court by way of originating notice within ...

s. 14(1)-Where an agent who is a principal under a bond mentioned in section 10 has a judgment obtained against him, his desig. nated representative or a salesman em. ployed by him which

(a) is based on a finding or fraud or breach of trust in respect of a trade in real estate,
Limitation Period

forthwith.

as soon as possible.

five days of the suspension, exclusive of holidays.

five days, exclusive of holidays, of the date of receipt of the request.

15 days of the conclusion of an inquiry pursuant to section 29 or 30 .

18 months from the time when the subject matter of the proceedings arose. 30 days of the date that person was served with the notification that his licence was cancelled or suspended.

30 days of being served with the notice of appeal.

30 days of the date upon which that person was served with the decision of the appeal board. 
Statute

\section{Action or Remedy}

(b) has become final by reason of lapse of time or of being confirmed by the highest court to which that judgment may be appealed, and

(c) is not satisfied within ...

the bond is forfeited upon the Superintendent notifying the surety in writing that the judgment remains unsatisfied ...

s. 14(2)-Where a bond is forfeited under subsection (1), the surety shall pay to the Minister

(a) the amount of the judgment in respect of which that bond was forfeited within ..., and

(b) the amount of any other judgment against that agent who was the principal under that bond, his designated representative or a salesman employed by him which

(i) is based on a finding of fraud or breach of trust in respect of a trade in real estate,

(ii) has, within ..., become final by reason of lapse of time or of being confirmed by the highest court to which the judgment may be appealed, and

(iii) remains unsatisfied ...

within ...

s. 14(3)-Where the Minister receives money under subsection (2), he shall pay that money into the Court in trust for those persons who obtained judgments referred to in subsection (2) and upon receiving all the money payable under subsection (2) the Court shall, after..., pay out that money to those persons who obtained those judgments.

s. 14(4)-Where

(a) the total amount paid to the Minister by the surety under subsection (2) is less than the face value of the bond forfeited under subsection (1),

(b) within ..., an action is commenced against that agent who was the principal under that bond, his designated representative or a salesman employed by him alleging fraud or breach of trust in respect of a trade in real estate, and

(c) judgment is obtained in that action against that agent, his designated representative or a salesman employed by him which

(i) is based on a finding of fraud or breach of trust in respect of a trade in real estate,

\section{Limitation Period}

30 days of the date that it becomes final,

30 days after the date that it becomes final.

60 days of the date that the bond was forfeited.

two years of the date that the bond was forfeited.

30 days after the judg. ment became final.

60 days of being notified in writing by the Superintendent that the judg. ment has become final.

two years have expired from the date the bond was forfeited.

two years of the date the bond was forfeited. 
Statute

The Temporary AntiInflation Measures Act, S.A. 1975 , c. 83

\section{Action or Remedy}

(ii) has become final by reason of lapse of time or of being confirmed by the highest court to which the judgment may be appealed, and

(iii) remains unsatisfied ...

the surety shall pay to the Minister the amount of the judgment within ...

s. 18.3(1)-Any person aggrieved by an order of the Superintendent made pursuant to section 18.1 or 18.2 may, within ..., appeal to the Court by way of originating notice.

s. 43(3)-Where a purchaser, tenant, or licensee has entered into a contract to which subsection (1) applies, he may rescind the contract

(a) within ..., or

(b) if subsection (1) has not been complied with.

s. 44.1(1)-The Superintendent may require that a prospectus filed under section 42 contain

(a) an audited financial statement of the owner for the last fiscal year and reported upon by the owner's auditor, and

(b) current unaudited financial statements dated not more than ... where the audited financial statements are dated more than ...

s. 21-The Lieutenant Governor in Council may, within ...., either upon petition of any person affected by the order or of his own motion, by order, rescind the order of the Board or instruct the Board to vary its order pursuant to the authority vested in it by section 19 in a manner specified in the order of the Lieutenant Governor in Council, and an order made by the Lieutenant Governor in Council under this section is binding on the Board upon a copy thereof, certified by the Clerk of the Executive Council, being sent to the Board and each person against whom the order of the Board was made by or on behalf of the Clerk of the Executive Council by registered mail or in such manner as is prescribed by the regulations.

8. 27(1)-Any person

(a) against whom an order has been made by the Alberta Board pursuant to section 17 or 18 , or

(b) who is affected by a variation pursuant to section 19 , without his consent, of an order referred to in clause (a) that was made against him,

may appeal to the Appeal Board, but no appeal under this section may be instituted after the expiration of ...
Limitation Period

30 days after the judg. ment becomes final, 60 days of being notified in writing by the Superintendent that the judg. ment has become final.

30 days thereof.

30 days of entering into the contract.

90 days prior to the date of the acceptance of the prospectus by the $\mathrm{Su}$ perintendent.

120 days prior to the date that the prospectus was submitted to the Superintendent for filing.

30 days of receipt by the Clerk of the Executive Council of a copy of an order made by the Board,

60 days from the day the order pursuant to section 17,18 or 19 , as the case may be, was made. 
Statute

\section{Action or Remedy}

The Temporary Rent Regulation Measures Act, S.A. 1975 , c. 84 . s. 7(4)-Where a landlord of residential premises wishes to make a permitted increase and the premises are vacant or will become vacant by reason of a landlord having given notice of termination of ten. ancy, the landlord shall give to a rent regulation officer a written notice of the in. crease in the rental rate at least ...

s. 8(2)-An application under subsection (1) shall

(a) be in writing,

(b) state the reasons why a greater increase in the rental rate than the permitted increase should be approved by the rent regulation officer,

(c) be made at least ....

(d) state the base rent of the residential premises,

(e) state whether or not the residential premises are vacant, and

(f) state the number of increases in the rental rate that have come into effect in respect of the residential premises on or after January $1,1976$.

s. 10(2)-The landlord may, within ...

(a) reduce the proposed increase in the rental rate to such an amount, not exceeding the premitted increase and notify the rent regulation officer and the tenant in writing accordingly, or

(b) notify the tenant and the rent regulation officer that the notice of increase in rent is withdrawn.

s. 11(1)-The rent regulation officer shall within .... consider the application and any statement of interest filed and after making such inquiry as he considers necessary, may, by order

(a) grant, vary or refuse any application in whole or part

(b) direct the landlord to repay to the tenant any moneys paid in excess of the amount which he has fixed in his order under this section or that the excess by set off by way of abatement of rent;

(c) direct the tenant to pay to the landlord any amount of money owing to the landlord by reason of the decision of the rent regulation officer,

and shall serve a copy of the order on the landlord and each tenant affected by it.

s. 11(3)-Where a rent regulation officer fails to give a decision within ...., the application shall be deemed

(a) to have been refused with respect to that amount that is greater than the permitted increase, and

(b) to have been a notice to the tenant in accordance with section 21 of The Landlord and Tenant Act for the permitted increase and shall take effect accordingly.

\section{Limitation Period}

90 days before the date on which the increase is to be effective.

90 days before the increase is proposed to be effective.

15 days of his receipt of a statement from a tenant under subsection (1).

60 days of his receipt of an application by a landlord under section 8 .

60 days of his receipt of a landlord's application under section 8 . 
Statute

The Trust Companies Act, R.S.A. 1970, c. 372 , as amended by 1975 , c. 85.

The Unfair Trade Practices Act. S.A. 1975 , c. 33.

The Water Resources Act, R.S.A. 1970 , c. 388 as amended by 1975 , c. 88 .

\section{Action or Remedy}

8. 12(1)-Until

(a) a rent regulation officer or on appeal, the Board, serves a copy of his or its order, or

(b) the expiration of ....,

s. 27(1)-A landlord or a tenant may, within ...., appeal to the Board by filing a written notice of the appeal with the Board.

8. 28(1)-Within ..., a landlord or a tenant affected thereby may file with the Board written arguments with respect to the report and the recommendations or either of them.

s. 28(2)-The Board, upon the expiration of ... may

(a) hold a hearing, or

(b) authorize one or more members of Board to inquire and report pursuant to section 19.

8. 126.1(4)-The Director

(a) may by notice direct any company to sell any real estate acquired by it under this section within .... and

(b) shall, pursuant to section 172 subsection (1), clause (a), disallow as assets of the company any real estate that is the subject of a notice under clause (a) as if it were an unauthorized investment, where the direction in the notice is not complied with.

s. 136(1)-Where a registered company proposes to make a loan and

(a) the amount to be advanced to the borrower is to be less than the principal amount repayable under the loan, or

(b) the principal amount repayable under the loan will include any fees or charges whether payable to the company or any other person,

the company shall deliver to the borrower a statement at least ...

8. 11(5)-Where a consumer commences an action under this section, he shall not take the next step in the action until...

8. 44(5)-A licensee whose licence has been suspended or cancelled under subsection (3), clause (a) may, within . . . , appeal the suspension or cancellation to a judge of the Supreme Court.

8. 44(6)-The appeal shall be the way of motion on notice, filed with the Clerk of the Supreme Court, and setting out the grounds of appeal and shall be served on the Minister not less than...

\section{Limitation Period}

60 days from the date the landlord's application under section 8 was received by the rent regulation officer.

15 days of the date of an order of a rent regulation officer under section 11 or section 15.

10 days of the date that a report and recom. mendations are sent to the Board pursuant to section 14.

10 days from the date a report and recommendations are sent to it pursuant to section 14 .

60 days or such longer period as he may allow.

24 hours before the time the loan contract is signed by the borrower showing the information prescribed by the regulations.

he has served the Director under subsection (4).

30 days of receipt of the order.

14 days before the returnable date shown on the notice. 